U.s. Army

Coast. Eng. Res. Ctr.

CDM 76-1

\title{
A Simplified Method for Determining Vertical Breakwater Crest Elevation Considering Wave Height Transmitted by Overtopping
}

by

William N. Seelig

COASTAL DESIGN MEMORANDUM NO. 76-1

MAY 1976
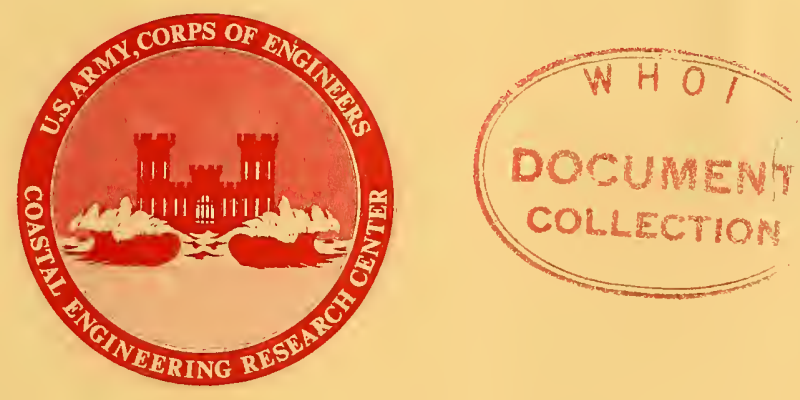

Approved for public release; distribution unlimited.

Kingman Building

U.S. ARMY, CORPS OF ENGINEERS

COASTAL ENGINEERING RESEARCH CENTER

Fort Belvoir, Va. 22060 
Reprint or republication of any of this material shall give appropriate credit to the U.S. Army Coastal Engineering Research Center.

Limited free distribution within the United States of single copies of this publication has been made by this Center. Additional copies are available from:

National Technical Information Service ATTN: Operations Division 5285 Port Royal Road Springfield, Virginia 22151

The findings in this report are not to be construed as an official Department of the Army position unless so designated by other authorized documents.

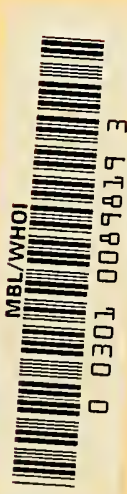




\begin{tabular}{|c|c|}
\hline REPORT DOCUMENTATION PAGE & $\begin{array}{c}\text { READ INSTRUCTIONS } \\
\text { BEFORE COMPLETING FORM }\end{array}$ \\
\hline $\begin{array}{l}\text { 1. REPORT NUMEER } \\
\text { CDM } 76-1\end{array}$ & 3. RECIPIENT'S CATALOG NUMBER \\
\hline \multirow{2}{*}{$\begin{array}{l}\text { 4. TITLE (and Subttte) } \\
\text { A SIMPLIFIED METHOD FOR DETERMINING VERTICAL } \\
\text { BREAKWATER CREST ELEVATION CONSIDERING WAVE } \\
\text { HEIGHT TRANSMITTED BY OVERTOPPING }\end{array}$} & $\begin{array}{l}\text { 5. TYPE OF REPORT \& PERIOO COVEREO } \\
\text { Coastal Design Memorandum }\end{array}$ \\
\hline & 6. PERFORMING ORG. REPORT NUMBER \\
\hline $\begin{array}{l}\text { 7. AUTHOR(O) } \\
\text { William N. Seelig }\end{array}$ & 8. CONTRACT OR GRANT NUMBER(B) \\
\hline $\begin{array}{l}\text { 9. PERFORMING ORGANIZATION NAME AND ADDRESS } \\
\text { Department of the Army } \\
\text { Coastal Engineering Research Center (CERRE-CS) } \\
\text { Kingman Building, Fort Belvoir, Virginia 22060 }\end{array}$ & $\begin{array}{l}\text { 10. PROGRAM ELEMENT, PROJECT, TASK } \\
\text { AREA \& WORK UNIT NUMBERS }\end{array}$ \\
\hline \multirow{2}{*}{$\begin{array}{l}\text { 11. CONTROLLING OFFICE NAME AND ADDRESS } \\
\text { Department of the Army } \\
\text { Coastal Engineering Research Center } \\
\text { Kingman Building, Fort Belvoir, Virginia } 22060 .\end{array}$} & $\begin{array}{l}\text { 12. REPORT DATE } \\
\text { May } 1976\end{array}$ \\
\hline & $\begin{array}{l}\text { 13. NUMBER OF PAGES } \\
16\end{array}$ \\
\hline \multirow[t]{2}{*}{ 14. MONITORING AGENCY NAME a ADDRESS(if different from Controlling Olfice) } & $\begin{array}{l}\text { 15. SECURITY CLASS. (of thle report) } \\
\text { UNCLASSIFIED }\end{array}$ \\
\hline & $\begin{array}{l}\text { 15. DECLASSIFICATION/DOWNGRADING } \\
\text { SCHEDULE }\end{array}$ \\
\hline
\end{tabular}

Approved for public release; distribution unlimited.

17. DISTRIBUTION STATEMENT (of the abetract entered in Block 20, if different from Report)

18. SUPPLEMENTARY NOTES

19. KEY WORDS (Continue on reverse side it necessary and Identify by block number)

Crest elevation

Vertical breakwater design

Wave overtopping
Wave regeneration

Wave transmission

20. ABSTRACT (Continue on reverse side if necoseary and ldentify by block number)

A method is presented for the design of vertical-faced breakwaters for wave transmission by overtopping based on laboratory experiments of Goda, Takeda, and Moriya (1967) and Goda (1969). A step-by-step procedure is outlined, design curves are presented, and examples worked to illustrate the procedure. 
This memorandum describes a method for determining the crest height of vertical-faced breakwaters considering allowable wave regeneration by overtopping. It is based on laboratory work and data analysis reported by Goda, Takeda, and Moriya (1967) and Goda (1969). The work was carried out under the coastal structures program of the U.S. Army Coastal Engineering Research Center (CERC).

The technical guidelines presented in this memorandum are intended to augment the procedures described in the "Shore Protection Manual" (SPM), Section 7.23, "Wave Transmission" (U.S. Army, Corps of Engineers, Coastal Engineering Research Center, 1975); the discussion in the SPM is limited to thin and wide submerged impermeable breakwaters and broad-crested, permeable rubble-mound breakwaters.

The memorandum was prepared by William N. Seelig, Research Hydraulic Engineer, Coastal Structures Branch, under the general supervision of Dr. R.M. Sorensen, Chief, Coastal Structures Branch.

Comments on this publication are invited.

Approved for publication in accordance with Public Law 166, 79th Congress, approved 31 July 1945, as supplemented by Public Law 172, 88 th Congress, approved 7 November 1963.

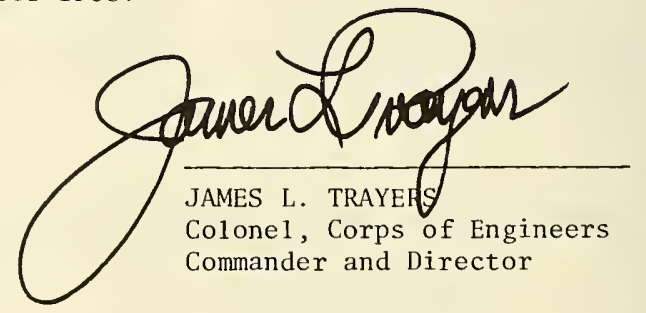




\section{CONTENTS}

Page

SYMBOLS AND DEFINITIONS . . . . . . . . . . . . . . . . 4

I INTRODUCTION . . . . . . . . . . . . . . . . . . 5

I I BREAKWATER CREST HEIGHTS . . . . . . . . . . . . . . . . . . . 5

I I SAMPLE DESIGN PROBLEMS . . . . . . . . . . . . . . . . . . . 6

IV SUMMARY . . . . . . . . . . . . . . . . . . . . . 16

FIGURES

1 Definition of terms and symbols .. . . . . . . . . . . . . 7

2 Freeboard for vertical-wall and vertical thin-wall

breakwaters (dimensionless) . . . . . . . . . . . . . . 8

3 Freeboard for composite breakwaters (dimensionless) . . . . . . . 9

4 Freeboard for vertical thin-wall breakwaters. . . . . . . . . . 10

5 Freeboard for vertical-wall breakwaters . . . . . . . . . . . 11

6 Freeboard for composite breakwaters . . . . . . . . . . . . . . 12

7 Freeboard for composite breakwaters . . . . . . . . . . . . 13

8 Freeboard for composite breakwaters . . . . . . . . . . . . . 14 
crest width

$\mathrm{d}_{S}$

water depth (feet)

$\mathrm{d}_{w}$

water depth at the base of the vertical face of a composite structure

$\mathrm{H}_{i} \quad$ incident wave height (feet)

$\mathrm{H}_{t} \quad$ transmitted wave height (feet)

$\left(\mathrm{h}-\mathrm{d}_{s}\right)$ freeboard (total height of structure - stillwater depth) (feet)

L incident wavelength (feet)

T wave period (seconds)

$\alpha \quad$ dimensionless parameter

B dimensionless parameter 
A SIMPLIFIED METHOD FOR DETERMINING VERTICAL BREAKWATER CREST

ELEVATION CONSIDERING WAVE HEIGHT TRANSMITTED BY OVERTOPPING

\author{
by \\ Wizliam N. Seelig

\section{INTRODUCTION}

The function of a breakwater is to lower wave heights in an area to be protected, where the final design depends on the incident wave conditions, protection criteria, cost, and environmental considerations. Wave energy can be transmitted to the lee of a structure by regeneration of waves by wave overtopping of the structure, propagation through the structure if sufficiently porous, and diffraction through openings in the breakwater. This design memorandum discussed wave regeneration by overtopping for three types of vertical-faced impermeable breakwaters: vertical thin-wall breakwaters, vertical-wall breakwaters, and composite breakwaters (see Section 7.23 of the Shore Protection Manual (SPM) (U.S. Army, Corps of Engineers, Coastal Engineering Research Center, 1975) ${ }^{1}$ for discussion of wave transmission).

\title{
II. BREAKWATER CREST HEIGHTS
}

Goda, Takeda, and Moriya $(1967)^{2}$ and Goda $(1969)^{3}$ performed extensive wave transmission by overtopping laboratory tests for a variety of structures. They found that wave regeneration by overtupping for verticalfaced breakwaters is given by:

$$
\mathrm{H}_{t}=0.5 \mathrm{H}_{i}\left\{1-\sin \left[\frac{\pi}{2 \alpha}\left(\frac{\mathrm{h}-\mathrm{d}_{s}}{\mathrm{H}_{i}}+\beta\right)\right]\right\} \text {, }
$$

where $\mathrm{H}_{t}$ is the average transmitted height (which will have different wave height and period characteristics than the incident wave), $H_{i}$ is the incident wave height (assumed to approach the structure normally), and $\left(\mathrm{h}-\mathrm{d}_{\mathcal{S}}\right.$ ) is the breakwater crest height or freeboard above the local water leve1.

${ }^{1}$ U.S. ARMY, CORPS OF ENGINEERS, COASTAL ENGINEERING RESEARCH CENTER, Shore Protection Manual, 2d ed., Vols. I, II, and III, Stock No. 008-02200077 , U.S. Government Printing Office, Washington, D.C., 1975, 1,160 pp.

${ }^{2}$ GODA, Y., TAKEDA, H. , and MORIYA, Y., "Laboratory Investigation of Wave Transmission over Breakwaters," Report of the Port and Harbour Research Institute, No. 13, Apr. 1967.

${ }^{3}$ GODA, Y., "Reanalysis of Laboratory Data on Wave Transmission over Breakwaters," Report of the Port and Harbour Research Institute, Vo1. 18, No. 3, Sept. 1969. 
The empirical coefficients, $\alpha$ and $B$, are determined from laboratory experiments for the three breakwater types for water depth to wavelength $(\mathrm{d} / \mathrm{L})$ ratios of $0.14 \leq \mathrm{d} / \mathrm{L} \leq 0.5$. The definition of terms and symbols is shown in Figure 1. Note that the crest width, $B$, is approximately zero for the thin-wall breakwater, and $B$ is approximately equal to the water depth for the other breakwaters.

In most design situations the general incident wind-wave conditions are known and the desired wave conditions in the protected area are established; therefore the height of a structure of given form can be calculated. Rearranging equation (1) gives:

$$
\left(\mathrm{h}-\mathrm{d}_{S}\right)=\mathrm{H}_{i}\left[-\beta+\frac{2 \alpha}{\pi} \operatorname{Arcsin}\left(1-\frac{2 \mathrm{H}_{t}}{\mathrm{H}_{i}}\right)\right]
$$

which has been used to develop the design curves. Figures 2 and 3 are dimensionless plots of $\left(h-\mathrm{d}_{S}\right) / \mathrm{H}_{i}$ versus $\mathrm{H}_{t} / \mathrm{H}_{i}$; Figures 4 to 8 are plots of equation (2) in English units.

These curves can be used in several ways. If the incident height and transmitted height are given, the crest height can be determined. If the crest height is given and the incident height is known, transmitted height can be approximated.

\section{SAMPLE DESIGN PROBLEMS}

The following examples demonstrate the use of the techniques presented. Refer to the SPM (U.S. Army, Corps of Engineers, Coastal Engineering Research Center, 1975) ${ }^{1}$ for useful information in a total design problem (e.g., wave theory, a discussion of tides, storm surges, wave breaking).

GIVEN: $\quad H_{i}=5.0$ feet, $T=4.5$ seconds, and $d_{S}=12.0$ feet.

FIND: The freeboard, $\left(h-\mathrm{d}_{s}\right)$, of a vertical thin-wall breakwater with $\mathrm{H}_{t}=1.5$ feet.

SOLUTION: The design techniques in this memorandum apply to waves of $0.14 \leq \mathrm{d} / \mathrm{L} \leq 0.5$; first, check the value of $\mathrm{d} / \mathrm{L}$ as explained in the SPM, Section 2.231, and using the tables in Volume III (U.S. Army, Corps of Engineers, Coastal Engineering Research Center, 1975) ${ }^{1}$. In this problem:

$$
\mathrm{d} / \mathrm{L}_{O}=12.0 /\left(5.12 \times(4.5)^{2}\right)=0.116
$$

$I_{U}$.S. ARMY, CORPS OF ENGINEERS, COASTAL ENGINEERING RESEARCH CENTER, op. cit., p. 5 . 


\section{Vertical}

Thin-Wall Breakwater
$\alpha=1.8 \quad \beta=0.1$
$B \approx 0$

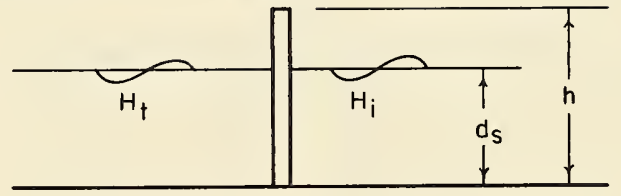

\section{Vertical-Woll \\ Breakwoter}

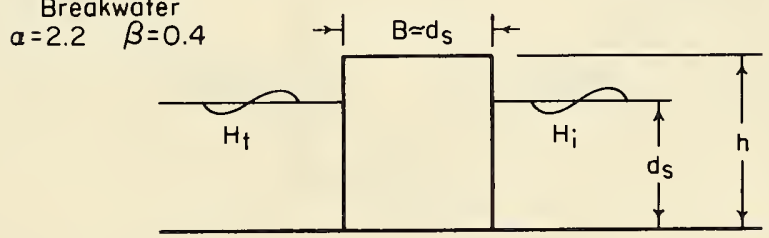

Composite

Breakwoter

$$
\mathrm{B} \simeq \mathrm{d}_{\mathrm{S}}
$$

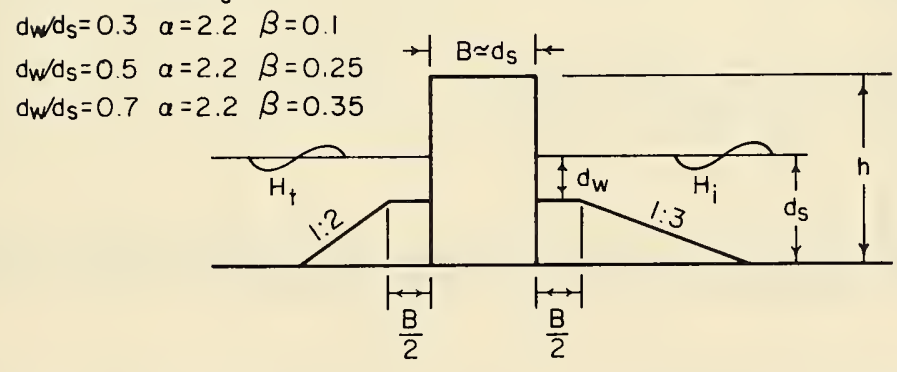

Figure 1. Definition of terms and symbols. 


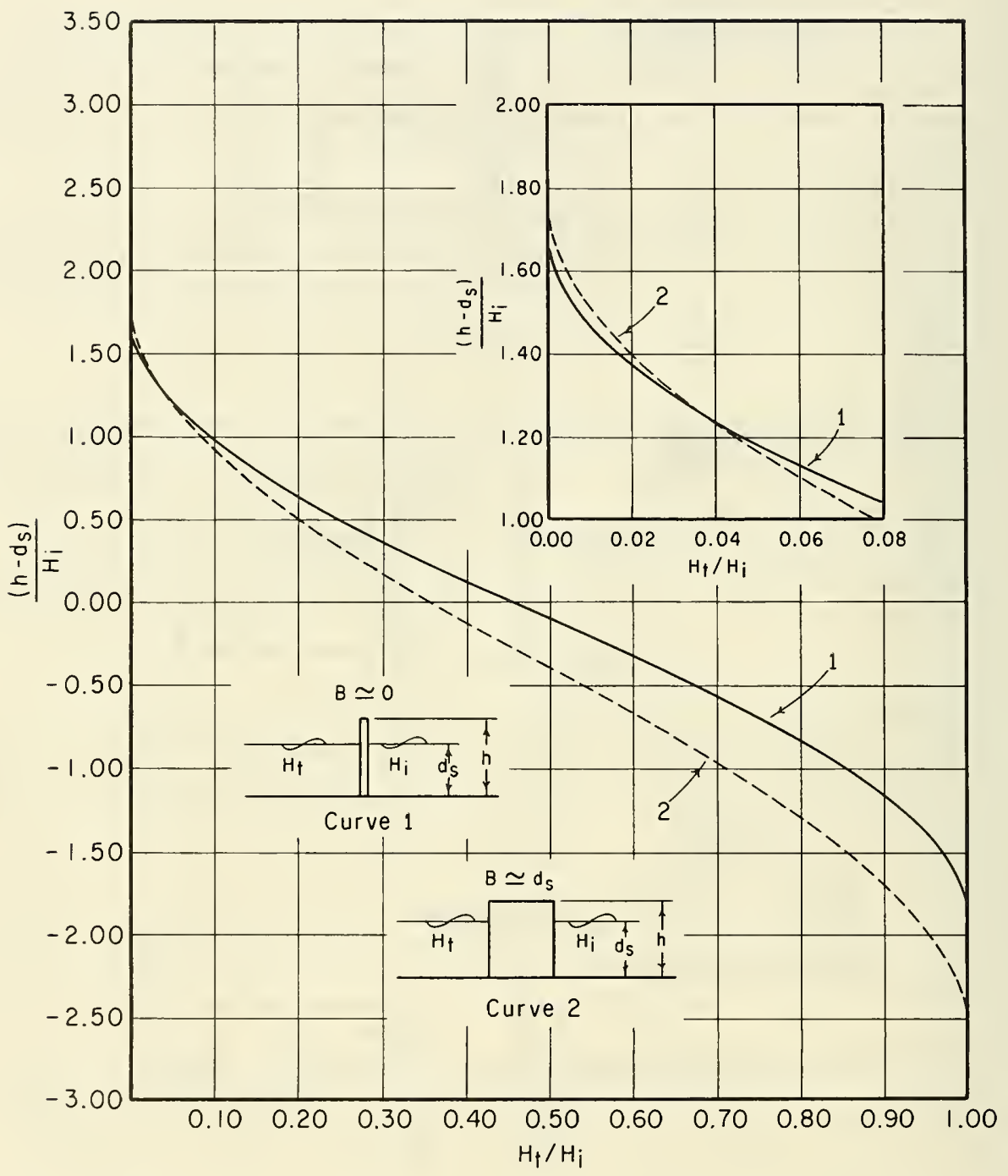

Figure 2. Freeboard for vertical-wall and vertical thin-wall breakwaters (dimensionless). 


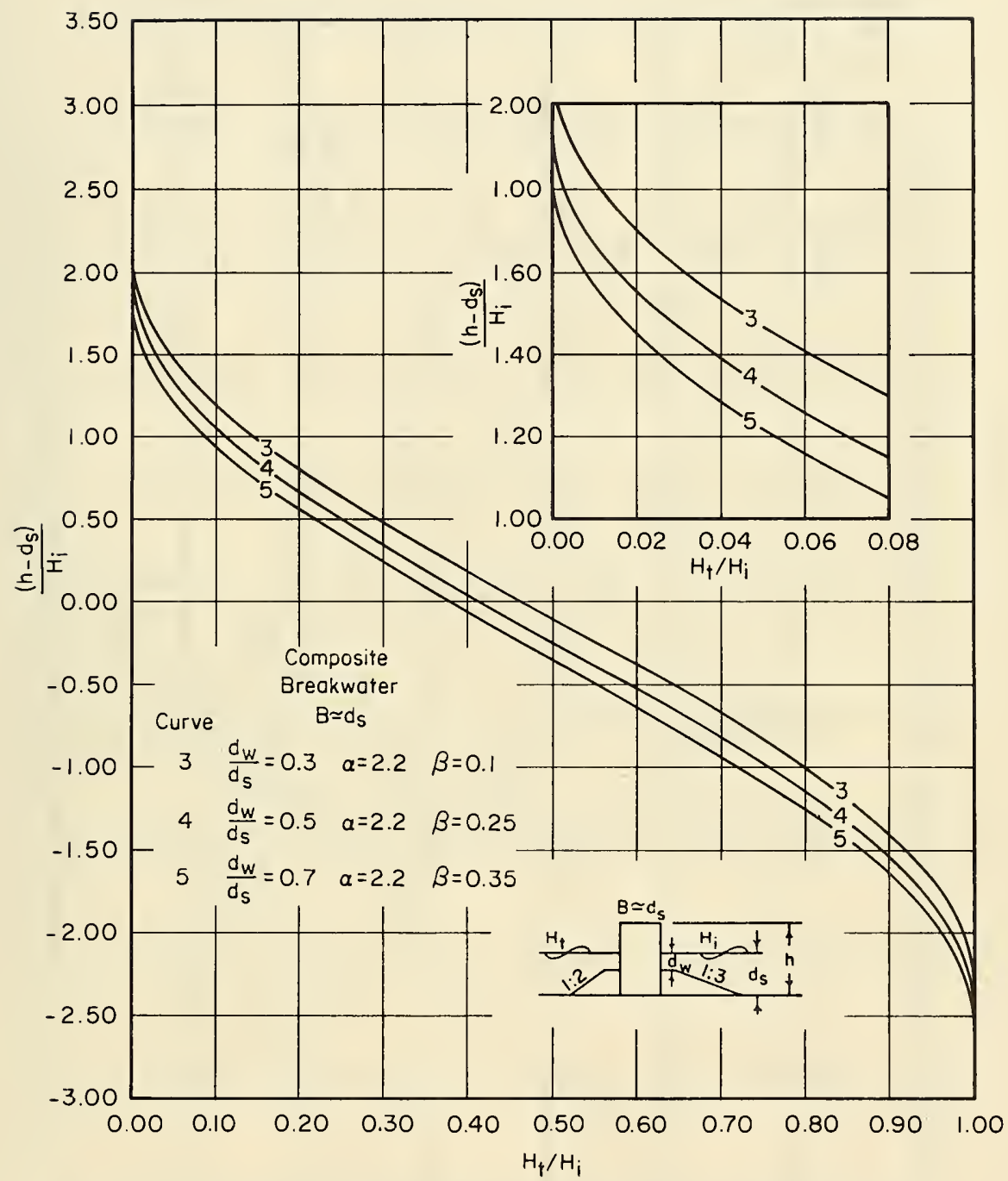

Figure 3. Freeboard for composite breakwaters (dimensionless). 


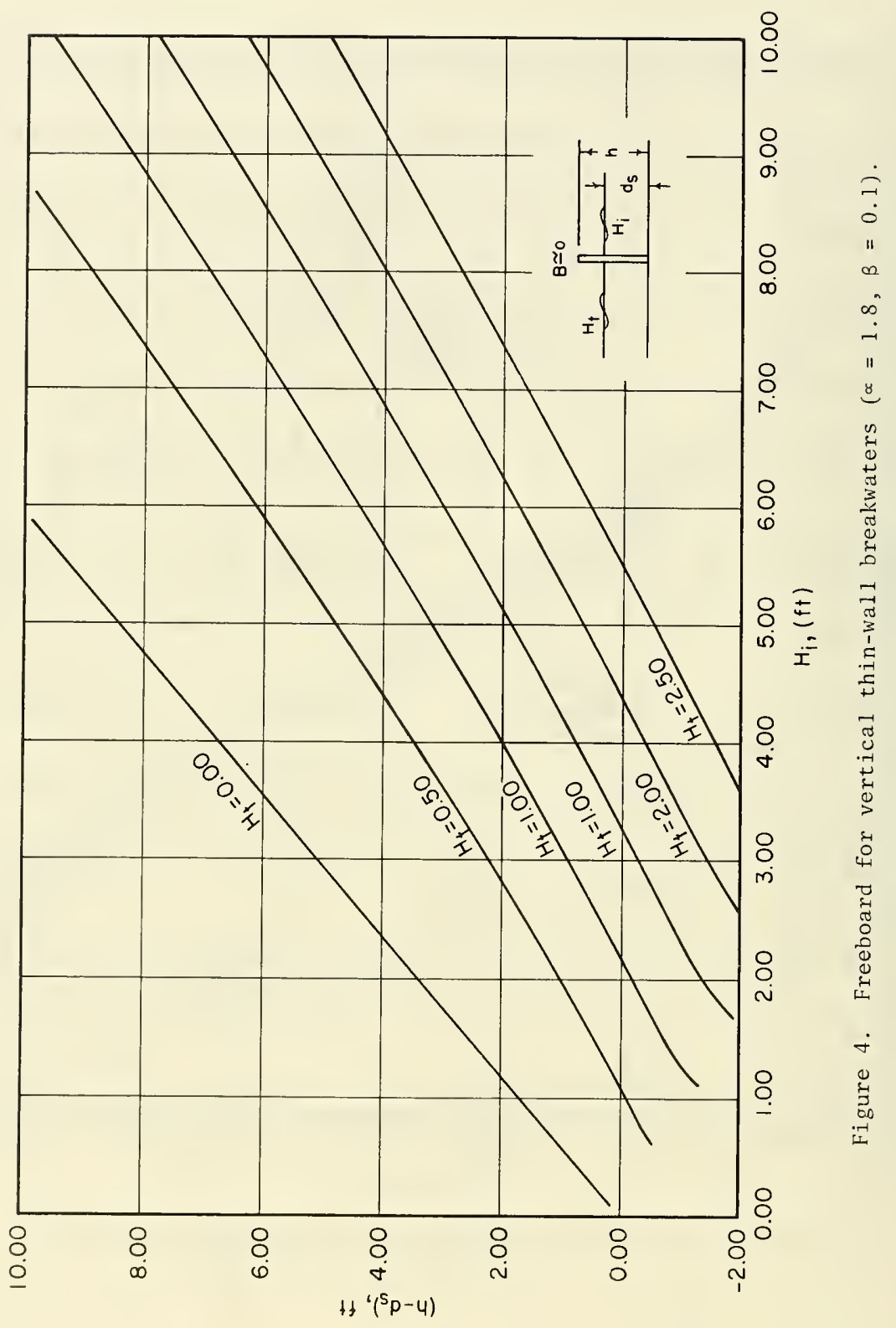




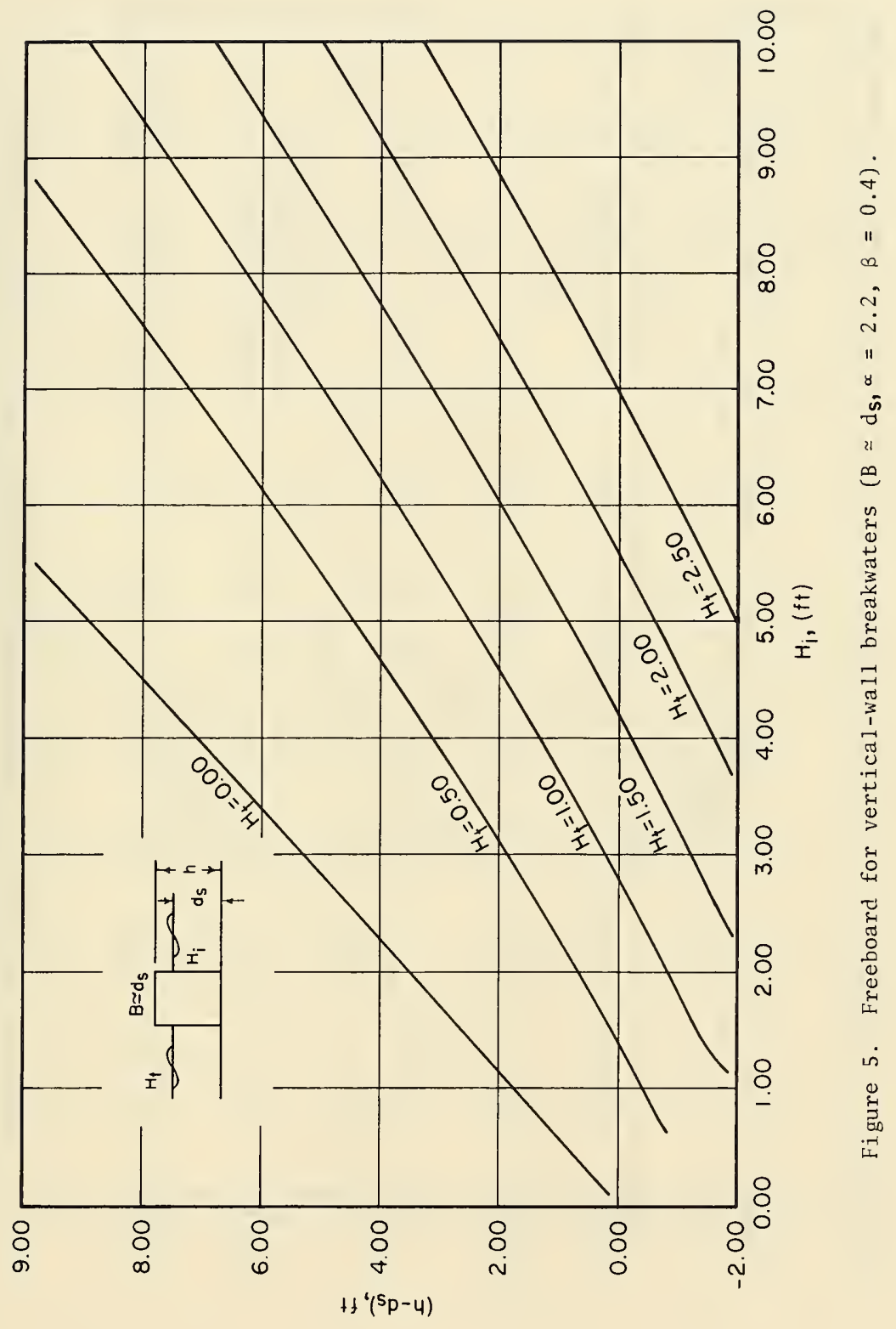




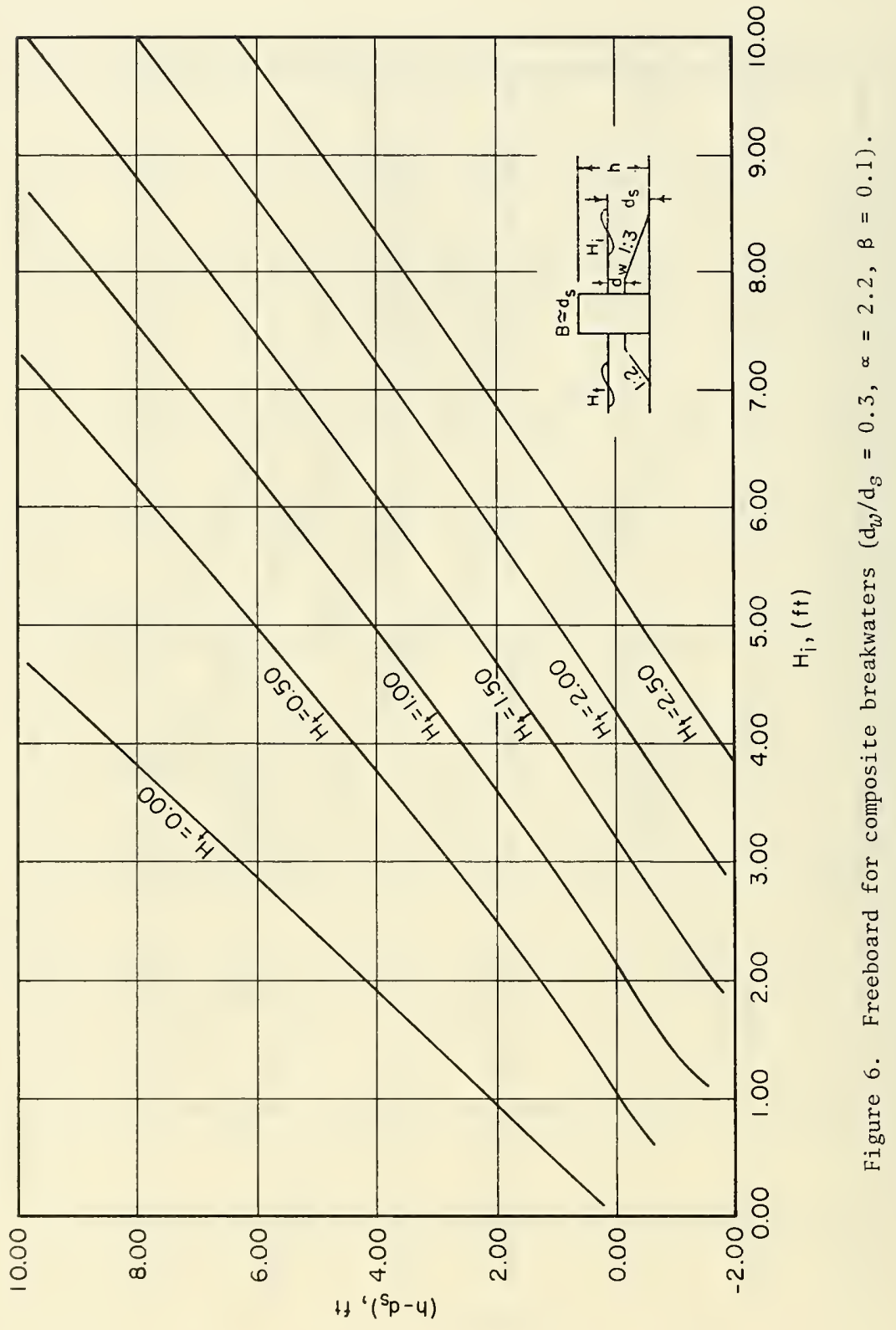




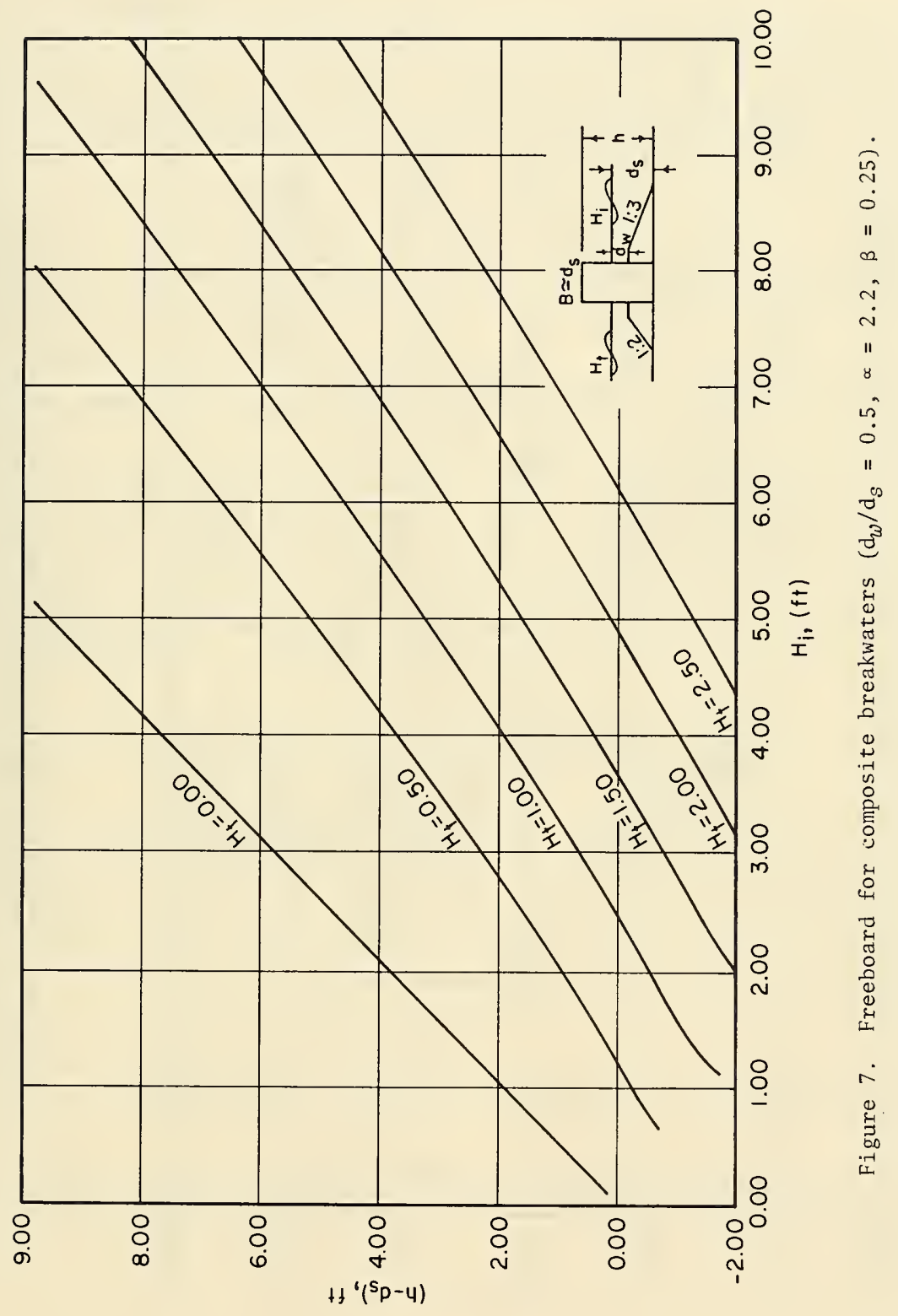




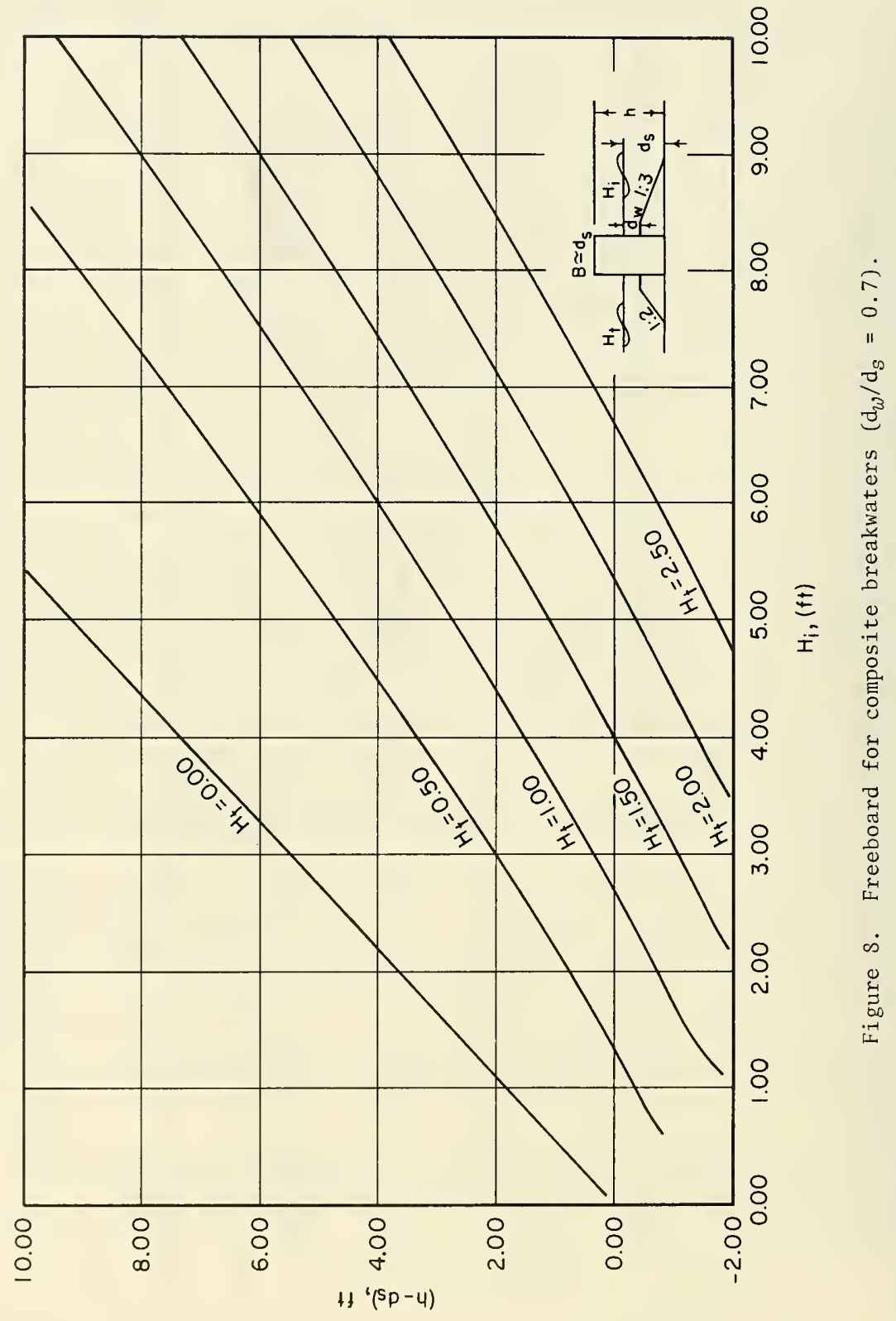


therefore, the technique applies. Second, check that the wave has not broken, or that $H_{i} / L \leq 0.143 \tanh 2 \pi \mathrm{d} / \mathrm{L}$. In this problem:

$$
\begin{aligned}
H / L=5.0 / 77.56 & \leq 0.143(0.7497) \\
0.0644 & <0.1072 ;
\end{aligned}
$$

therefore, the incident wave has not broken before reaching the structure.

Using Figure 2 (curve 1) or Figure 4 the freeboard, $\left(\mathrm{h}-\mathrm{d}_{S}\right.$ ), is determined as 1.75 feet.

GIVEN: $\quad H=5.0$ feet, $T=4.5$ seconds, and $d_{s}=12.0$ feet.

FIND: The freeboard of a vertical breakwater which has a crest width approximately equal to the water depth $\left(\mathrm{B} \simeq \mathrm{d}_{S}\right)$ with $\mathrm{H}_{t}=0.5$ foot.

SOLUTION: The $\mathrm{d} / \mathrm{L}$ and $\mathrm{H} / \mathrm{L}$ conditions of this problem fall into the required ranges (see problem 1). From Figure 2 (curve 2) or Figure 5 the freeboard is determined as 4.3 feet.

GIVEN: $H_{i}=5.0$ feet, $T=4.5$ seconds, and $d_{s}=12.0$ feet.

FIND: The transmitted wave height, $\mathrm{H}_{t}$, of a vertical breakwater $\left(\mathrm{B} \simeq \mathrm{d}_{s}\right)$ with the crest height at the water level, $\left(\mathrm{h}-\mathrm{d}_{S}\right)=0$.

SOLUTION: From Figures 2 (curve 2) and 5 the transmitted height is determined as 2.3 feet.

GIVEN: The conditions in problem 2 .

FIND: The freeboard for a composite breakwater, $\left(\mathrm{h}-\mathrm{d}_{s}\right)$, for $\mathrm{d}_{w} / \mathrm{d}_{s}=0.5$, with $\mathrm{H}_{t}=0.5$ foot.

SOLUTION: The $\mathrm{d} / \mathrm{L}$ and $\mathrm{H} / \mathrm{L}$ conditions of this problem fall into the required ranges (see problem 1). From Figure 2 (curve 4) or Figure 7 the $\left(\mathrm{h}-\mathrm{d}_{S}\right)=5.3$ feet. 
GIVEN: The conditions in problem 2 .

FIND: The transmitted height for a submerged thin-wall breakwater with $\left(\mathrm{h}-\mathrm{d}_{S}\right)=-1.0$ foot.

SOLUTION: Figure 2 (curve 1) or Figure 4 are used to find $H_{t}=2.8$ feet.

\section{SUMMARY}

The results of Goda, Takeda, and Moriya $(1967)^{2}$ and Goda $(1969)^{3}$ are used to design breakwaters for wave transmission by overtopping. To illustrate the transmission by different types of breakwaters, consider the case where the freeboard is equal to one-half the incident wave height: $\left(\mathrm{h}-\mathrm{d}_{s}\right) / \mathrm{H}_{i}=0.5$. The predicted dimensionless transmitted height is:

\begin{tabular}{|c|c|}
\hline BREAKWATER TYPE & $\mathrm{H}_{t} / \mathrm{H}_{i}$ \\
\hline Vertical thin wall & 0.25 \\
\hline Vertical $\mathrm{B} \simeq \mathrm{d}_{\mathrm{s}}$ & 0.20 \\
\hline Composite $\mathrm{d}_{w} / \mathrm{d}_{s}=0.3$ & 0.30 \\
\hline Composite $\mathrm{d}_{\omega} / \mathrm{d}_{S}=0.5$ & 0.25 \\
\hline Composite $\mathrm{d}_{\omega} / \mathrm{d}_{s}=0.7$ & 0.21 \\
\hline
\end{tabular}

For this condition, the vertical breakwater with a width approximately equal to the depth gives the smallest transmitted wave height; a composite structure gives the largest predicted transmitted wave.

${ }^{2}$ GODA, TAKEDA, and MORIYA, op. cit., p. 5.

${ }^{3}$ GODA, op. cit, p. 5 . 


\begin{tabular}{|c|c|c|c|c|c|c|c|}
\hline 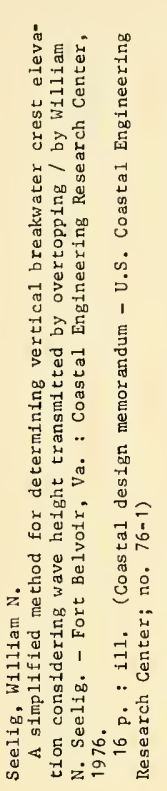 & 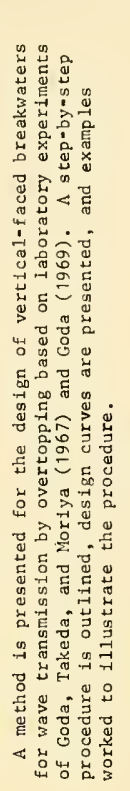 & 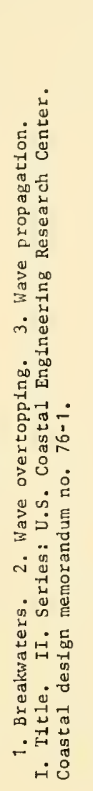 & $\begin{array}{l}\overline{\dot{\delta}} \\
\dot{\vdots}\end{array}$ & 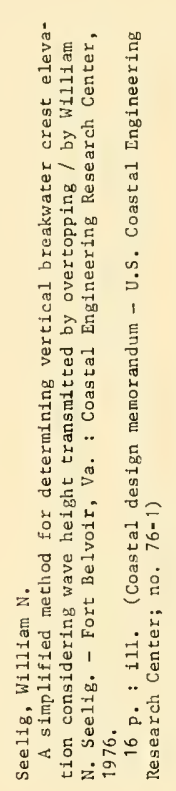 & 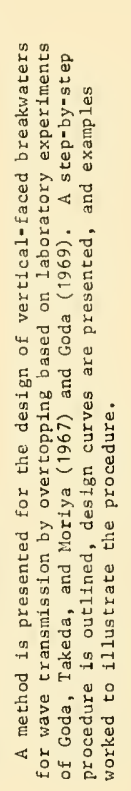 & 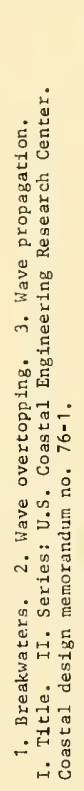 & $\begin{array}{l}\text { 틈 } \\
0 \\
0 \\
0 \\
?\end{array}$ \\
\hline 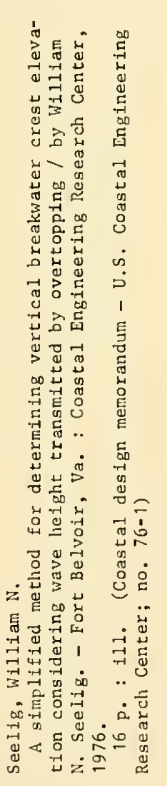 & 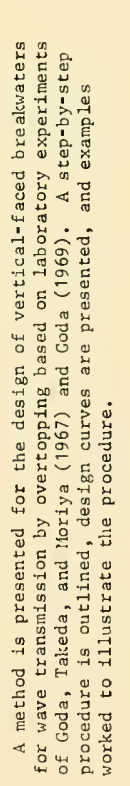 & 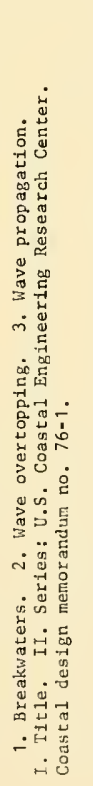 & $\begin{array}{l}\frac{E}{0} \\
\frac{0}{\infty} \\
\frac{0}{?} \\
\text { ?. }\end{array}$ & 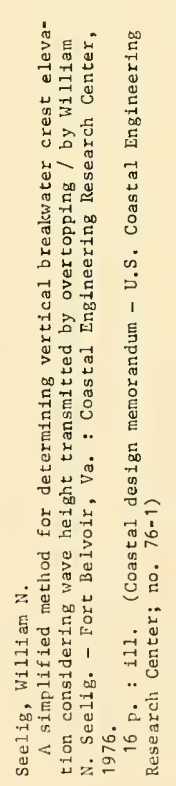 & 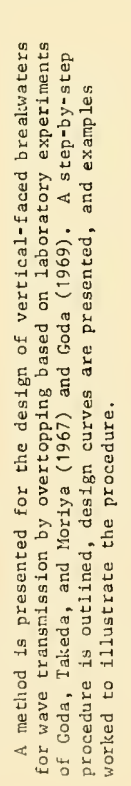 & 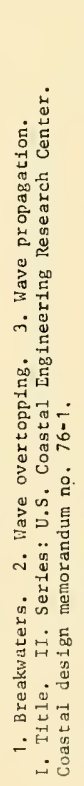 & 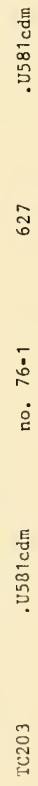 \\
\hline
\end{tabular}





\begin{tabular}{|c|c|c|c|c|c|c|c|}
\hline 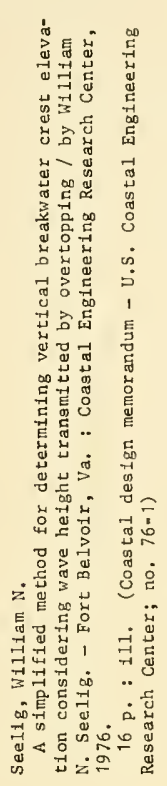 & 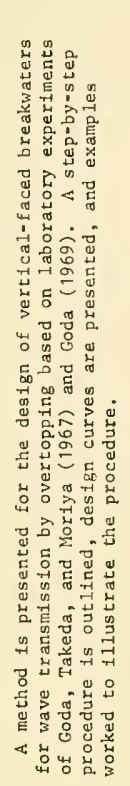 & 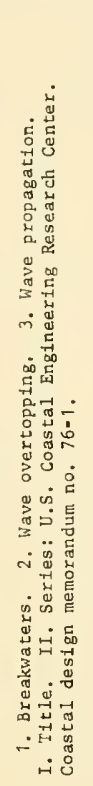 & $\begin{array}{l}\overline{\dot{b}} \\
\stackrel{0}{\circ} \\
\dot{0}\end{array}$ & 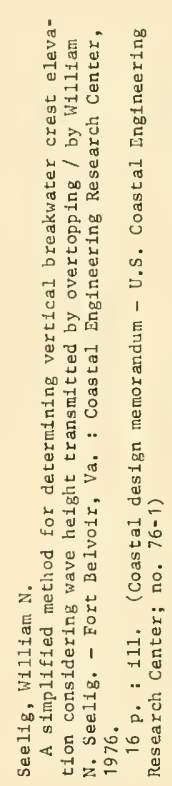 & 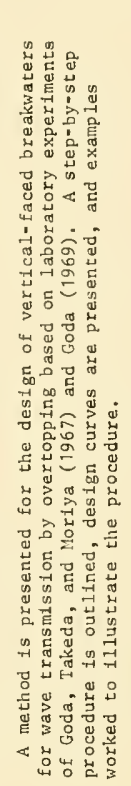 & 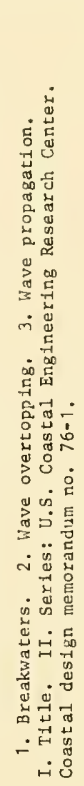 & 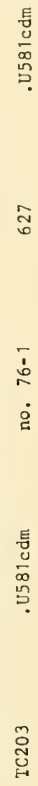 \\
\hline 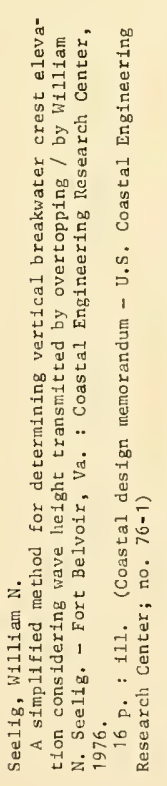 & 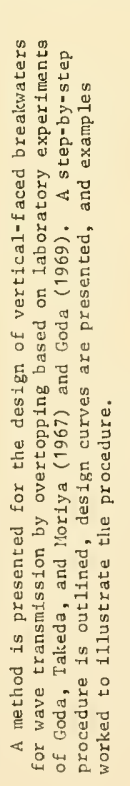 & 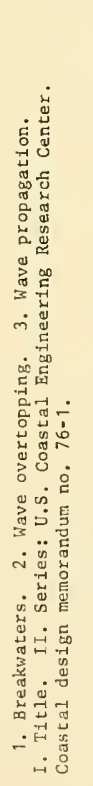 & $\begin{array}{l}\frac{\text { E }}{0} \\
\frac{0}{0} \\
\stackrel{0}{!}\end{array}$ & 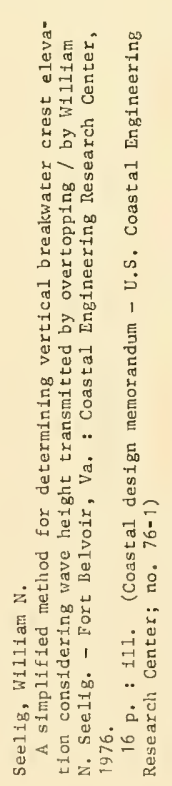 & 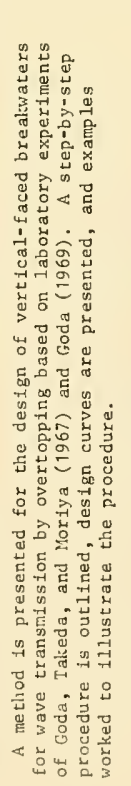 & 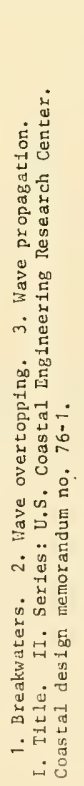 & $\begin{array}{l}\text { E్ } \\
\text { U } \\
\frac{5}{5} \\
\stackrel{0}{?}\end{array}$ \\
\hline
\end{tabular}




